\title{
2B04
}

\section{心理生理的因子が皮膚表面温度に 与える影響の検討}

\author{
○飯田 一郎 (侏コーセー 研究所) \\ 呂承シ、野呂 影勇 (早稲田大学 人間科学部)
}

\begin{abstract}
A Study on the Effect of Phycophysiological Factors to the Skin Temperature Ichiro Iida (KOSE Corporation, Research Laboratory)

Shosi Ro, Kageyu Noro (Waseda Univ., School of Human Sciences)
\end{abstract}

\section{1 .. 緒言}

皮㢆表面温度は皮漏生理状態の指標 ${ }^{1)}$ として 用いられている一方、リラクセーションやスト レス等の心理状態の指標としても着目されつつ ある。皮席表面温度は、多くの要因系に影響さ れており、これまで外的環境因子についての多 くの報告はあるものの、心理的要因、生活要因 との関係が十分に解析されていないのが現状で ある。本研究では心理状態の客観的指標の導出 とリラクセーションの評価への適用を目的とし ている。本報では心理、生理的状態と生活状況 等が皮成表面温度に与える影響について検討し た。

\section{2. 実験方法}

被験者は健康成人女性 7 名で、通常の生活環 境における測定を実施した。実験日を設定し、 朝、昼、夜の 3 回各々に測定、主観的評価、生 活状況アンケート等を実施した。各被験者につ いて以上の実験を 2 回実施した。

測定項目は煩、類の皮府表面温度、血圧、心 拍とした。主観的評価は 5 段階評価 6 項目、生 活状況は睡眠、体調等 5 項目を実施した。皮成 表面温度測定にはHORIBA製 INFRARED THERMOMETER IT-330 を使用した。

\section{3. 結果と考察}

皮府表面温度の変動要因の解析においては、 外れ値の検討後、36ケースに対して基本統計量 の予備的検討、皮成表面温度を目的変数とした 重回㷌分析、特性值に対する主成分分析を実施 した。Fig.-1にリラックス感と规部皮府表面温度 の関係を示した。リラックス感と皮成表面温度 は負の相関関俰にあり、心理的状態が皮成表面 温度に影響を与える点が示咍されている。

Table-1に被験者毎の皮府表面温度特性を示し た。平均値は被験者間で $2{ }^{\circ} \mathrm{C}$ 程度異なり、心理 的特性と関係づける場合、被験者間の差は要因 として考虑すべきである。Table-2に重回帰分析 結果を示した。説明変数として被験者、リラッ クス感、実験時の平均睡眠時間が選択された。 回帰モデルは自由度二重調整済寄与率が 0.693 と ほほ十分な説明力があると考えられる。スコア の検討によって被験者は 3 群に併合され、群毎 にモデルが導かれる。以上皮凧表面温度に対す ろ各変動要因の影響の検討によって、睡眠時間 のような生活習慣、リラックス感などの心理状 態の寄与が高い点が示された。

参考文献

1）飯田、峷岸、野呂; 日本人間工学会第34回大 会要旨集, p218 219（1993） 


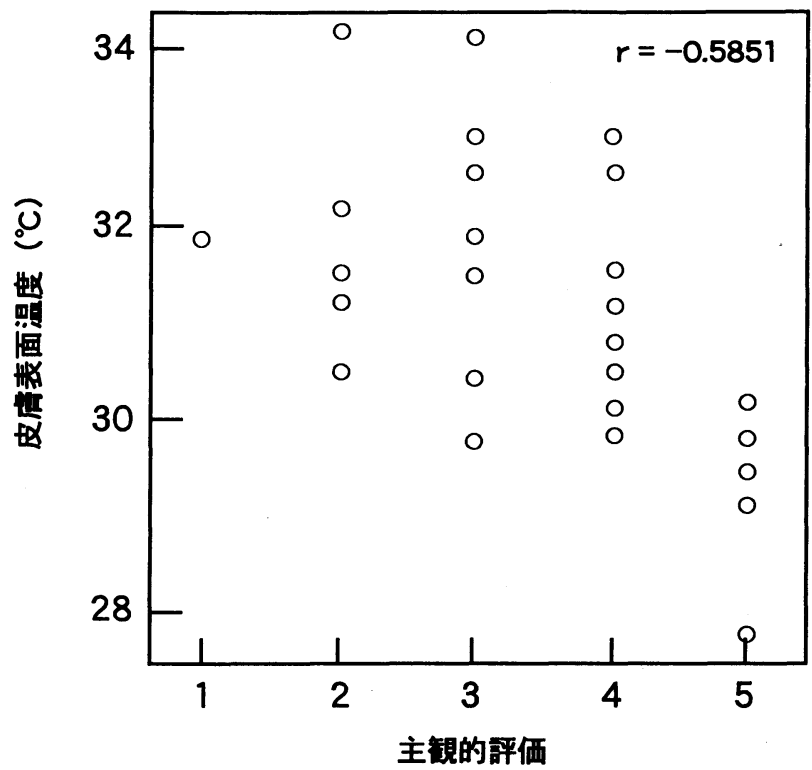

Fig. -1 皮虞表面温度（䅡）とリラックス感（主哯的評価）の関係

Table 1 皮虞表面温度（頑）と被検者の関係

\begin{tabular}{l|rrrrrrr}
\hline 被験者 & 1 & 2 & 3 & 4 & 5 & 6 & 7 \\
\hline 平均值 & 31.9 & 32.2 & 31.9 & 29.8 & 29.5 & 31.1 & 29.7 \\
標準偏差 & 0.784 & 1.32 & 1.24 & 0.551 & 1.27 & 0.883 & 0.0580 \\
\hline
\end{tabular}

Table 2 重回㱕分析の結果

\begin{tabular}{|c|c|c|c|c|c|c|}
\hline 説明変数 & \multicolumn{2}{|c|}{ 偏回㷌係数 } & $\mathrm{t}$ 值 & \multicolumn{2}{|c|}{ 㯲準偏回㛿係数 } & トレランス \\
\hline 定数 & & 26.121 & 19.664 & & \multirow[b]{2}{*}{-0.397} & \\
\hline リラックス感 & & -0.539 & -4.194 & & & 0.8843 \\
\hline 平均睡眠時间 & & 1.301 & 6.573 & & 0.776 & 0.5684 \\
\hline \multicolumn{2}{|l|}{ カテゴリー变数 } & & \multicolumn{3}{|c|}{$\mathrm{t}$ 值 } & \\
\hline \multicolumn{2}{|l|}{ 被験者群(併合) } & & 1 & 2 & 3 & \\
\hline \multirow{3}{*}{ スコアの差 } & 1 & & $\searrow$ & -4.194 & -6.126 & \\
\hline & 2 & & -1.294 & $\searrow$ & -3.443 & \\
\hline & 3 & & -2.678 & -1.384 & $\searrow$ & \\
\hline
\end{tabular}

目的变数 煩皮虞表面温度

残差平方和 $\quad 18.460$

寄与率 $\quad 0.755$

自由度調整済寄与率 0.723

二重調整済寄与率 0.693

残差の自由度

31

残差の㮏準偏差 $\quad 0.772$

カテゴリーの併合

被験者群 被験者

$1 \quad 1,2,4$

23,5

36,7 